\title{
Effects of the urban heat island and climate change on the growth of Khaya senegalensis in Hanoi, Vietnam
}

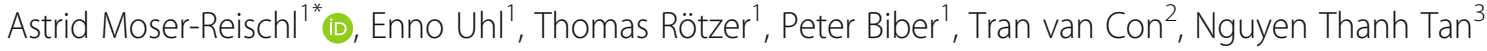 \\ and Hans Pretzsch ${ }^{1}$
}

\begin{abstract}
Background: Recent projections expect that Vietnam will be affected most severely by climate change with higher temperatures, more precipitation and rising sea levels. Especially increased temperatures will worsen the situations in cities, amplifying the urban heat island effect. Green infrastructures, i.e. urban trees are a common tool to improve the urban micro-climate for humans. Vital and well growing trees provide greatest benefits such as evaporative cooling, shading, air filtering and carbon storage. However, urban tree growth is often negatively affected by urban growing conditions such as high soil sealing with compacted tree pits providing small growing spaces with limited water, nutrient and oxygen supply, further warm temperatures and high pollution emissions. This study analyzed the growth of urban and rural African mahogany (Khaya senegalensis (Desr.) A. Juss.) trees in the city of Hanoi, Vietnam and the effects of the surrounding climate conditions on tree growth.
\end{abstract}

Results: The results showed that rural African mahogany trees grew better than trees situated in the city center, which is contrary to other results on tree growth of temperate and subtropical cities worldwide. Moreover tree growth was similar regardless of the time of growth. Other results regarding stem growth of African mahogany located in different areas of Hanoi (east, west, north, city center) revealed a better growth in the northern and western outskirts of the city compared to the growth of trees in the city center.

Conclusion: African mahogany trees in the urban centers of Hanoi showed a decreased growth compared to rural trees, which was likely induced by a low ground-water level and high pollution rates. In view of climate change and global warming, the decreased tree growth in the city center may also affect tree service provision such as shading and cooling. Those climate mitigation solutions are strongly needed in areas severely affected by climate change and global warming such as Vietnam.

Keywords: African mahogany, Dendrochronology, Ecosystem services, Urban tree growth

\section{Background}

Heat and heat-induced problems are important issues for arid and subtropical regions, in particular for highly urbanized areas (IPCC 2014; Klemm et al. 2015). Due to the urban heat island effect (Oke 1987; Coburn 2009), urbanized regions can be significantly warmer than the surrounding rural regions (Ballester et al. 2010; Seto et al. 2011; Klemm et al. 2015). In the next decades heat

\footnotetext{
* Correspondence: astrid.moser@|rz.tum.de

${ }^{1}$ Chair for Forest Growth and Yield Science, Center of Life and Food Sciences Weihenstephan, Technical University Munich, Hans-Carl-von-Carlowitz-Platz 2, 85354 Freising, Germany

Full list of author information is available at the end of the article
}

problems in urban areas will likely worsen due to increased urbanization and climate change effects. In subtropical regions, high temperatures together with high humidity can dramatically affect the thermal comfort and hence human-wellbeing in urban regions (Daanen et al. 2013; Santamouris 2014). As Schmidt-Thomé et al. (2015) points out, Vietnam will be affected by climate change most severely; It has been considered as a country suffering tremendously from increasing temperatures (annual average temperature has increased by $0.5{ }^{\circ} \mathrm{C}$ nationwide), changed precipitation (annual precipitation has decreased in the North and increased in the South) and rising sea 
water levels (IPCC 2001; Schmidt-Thomé et al. 2015). Mitigation measures and adaptation strategies to buffer the impacts of climate change on Vietnam are therefore extremely essential (Schmidt-Thomé et al. 2015). Possible solutions for climate change adaption and mitigation measures are urban green infrastructures, especially urban trees, which are getting increased attention due to their effects of ameliorating their surrounding micro-climate (Dimoudi and Nikolopoulou 2003; Foster et al. 2011; Roy et al. 2012). Urban trees influence the climate of a city by e.g. evapotranspiration and hence air cooling (Rahman et al. 2017a, 2017b) as long as water availability allows, shading (Akbari et al. 2001; Lee et al. 2013), air purification (Bell et al. 2011), wind buffering (Nowak and Dwyer 2007), carbon storage (Nowak and Crane 2002; Davies et al. 2011), reduction of rainwater-runoff (Armson et al. 2013), biodiversity preservation (de Groot et al. 2002; TEEB 2011) and esthetic features for recreation means (Tyrväinen et al. 2005).

However, ecosystem services provided by urban trees are highly related to the growing conditions of a tree, the individual tree size and age, tree vitality, species and specific species features such as wood anatomy and water stress behavior (Yoon et al. 2013; Konarska et al. 2015; Moser et al. 2015; Moser et al. 2016a; Rahman et al. 2017a). For example, anisohydric species react on drought stress with significant decreases of their leaf water potential, providing continued transpiration and hence air cooling as well as growth. Contrary, isohydric species maintain a consistent minimum leaf water potential (reduced transpiration) during drought stress to minimize water loss, however inducing higher latent heat exchange from the ground (Klein 2014; Sjöman et al. 2015). Moreover, broad-leaved species with full crowns provide more shading than species with small leaves and sparse crowns, as well as older and more vital trees (Moser et al. 2015).

Vitality and growth, though, are also highly related to the specific influences an urban tree is exposed to at its growing site. Often urban trees suffer from soil compaction (Bühler et al. 2007; Bartens et al. 2008) and small planting pits with limited water supply and nutrient availability as well as reduced aeration and growing space (Morgenroth and Buchan 2009; Rahman et al. 2013). Additionally the urban heat island can affect urban tree growth due to higher temperatures (higher temperatures can hinder photosynthesis and respiration, lead to membrane destruction (Akbari et al. 2001; Moser et al. 2016a; Rennenberg et al. 2006), higher $\mathrm{CO}_{2}$ concentrations and higher air pollution (Bussotti et al. 2014).

However, despite the often very negative effects of the urban climate on tree growth, several studies worldwide found an enhanced urban tree growth compared to rural trees (see for example Pretzsch et al. (2017) and Searle et al. (2012)). The study of Pretzsch et al. (2017) included dendrochronological samples of more than 1000 trees of ten metropolises worldwide, spanning from boreal cities to temperate and Mediterranean and subtropical cities. The resulting tree-ring chronologies reflect the past growth of urban trees, dating back more than 100 years, revealing the effects of global climate change and the urban heat island effect on urban tree growth worldwide.

Our study in Hanoi, Vietnam focuses on the urban tree species African mahogany (Khaya senegalensis) and its current and past growth in urban and rural areas. African mahogany was introduced to Hanoi; it is native in Africa and occurs along a broad range from Western Africa to Central Africa to Eastern Africa. It is one of the most important timber species in Africa, used e.g. for furniture, railroads and boats. Trees are growing to a maximum height of $30 \mathrm{~m}$ (Gaoue and Ticktin 2007). Due to its origin, African mahogany is adapted to moist regions with high rainfall though due to its deep root system it is very drought resistant. African mahogany is a common urban tree species worldwide, especially in tropical and subtropical regions such as Vietnam. Hanoi, with a population of 6.5 million inhabitants the second largest city of Vietnam, will also be affected most severely by climate change due to increased temperatures and precipitation levels (IPCC 2001; Schmidt-Thomé et al. 2015). This study analyzed the growth of a common urban and forest tree species in a subtropical city, highly affected by climate change. The results show how urban trees will be influenced by the urban heat island effect and climate change, helping to find common and practical solutions for mitigation measures to climate change with vital and benefitting green infrastructure. The underlying research questions of this study are:

- How is the general growth trend of $K$. senegalensis trees in Hanoi, Vietnam?

- Is the stem growth of urban K. senegalensis trees similar to the stem growth of rural trees?

- Do the past and the current stem growth rates of urban and rural K. senegalensis in Hanoi differ?

- How does the climate of Hanoi influence urban tree growth?

\section{Methods}

\section{Climate of Hanoi}

The climate of Hanoi (Hà N i), Vietnam is characterized by warm humid subtropical conditions with plentiful precipitation especially in summer, but a distinctly cool and dry season (DWD 2017) (Fig. 1). The cool season starts in November and lasts until April with temperatures of minimum $17{ }^{\circ} \mathrm{C}$, while the warm season spreads from May to 


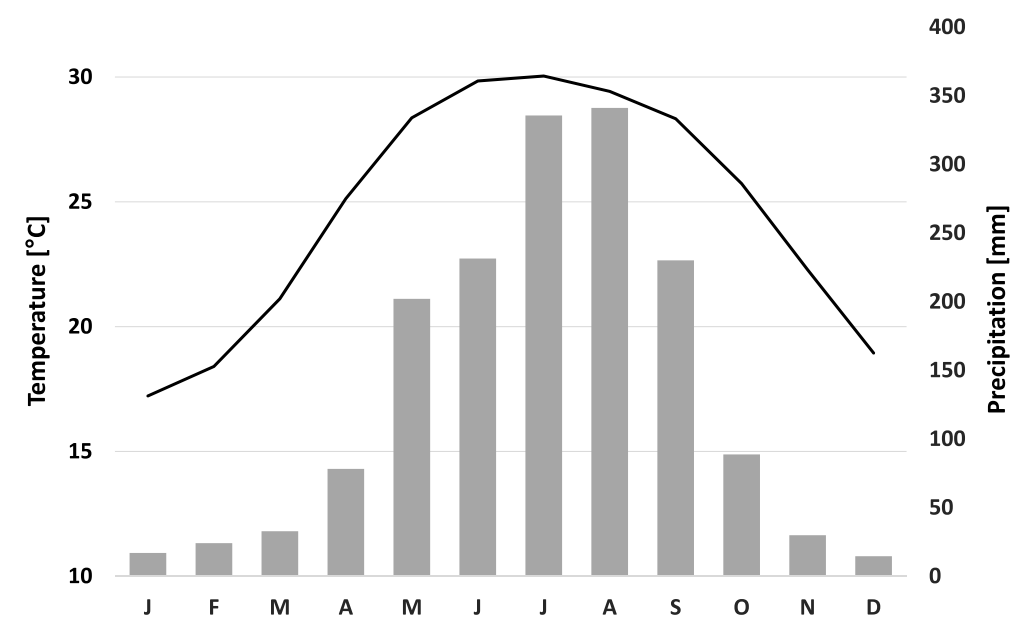

Fig. 1 Monthly temperature (Temp, black line) and precipitation (Prec, grey bars) in Hanoi, Vietnam from 1970 to 2007. Data source: DWD (2017)

October with maximum temperatures of $30{ }^{\circ} \mathrm{C}$. The long-term mean annual temperature is $24.6^{\circ} \mathrm{C}$ and the corresponding average precipitation amounts to $1626 \mathrm{~mm}$ per year (1970-2009). Over the past 50 years (1958-2007), the annual average temperatures of Vietnam have increased by about $0.5{ }^{\circ} \mathrm{C}$ to $0.7{ }^{\circ} \mathrm{C}$. The annual average precipitation does not show a clear trend across the country, however in northern regions a decrease of precipitation has been observed (FAO 2011). In Hanoi, temperatures increased about $0.44{ }^{\circ} \mathrm{C}$ in this period, while the precipitation decreased by about $113 \mathrm{~mm}$ (DWD 2017).

\section{Data collection}

In the city of Hanoi, 149 African mahogany trees were sampled randomly. Data collection was conducted at several sites mostly along streets throughout the city to include variation in site microclimate, urbanity and direction (Fig. 2, Table 1).

The degree of urbanity at each site was assigned to one of three categories: urban, suburban and rural. Trees in the inner city center were classified as urban (map numbers 8 , 12-16), while trees in the outer city center were marked as suburban (numbers 7, 9-11) and trees growing in the outskirts of the cities were sampled as rural trees (numbers 16). Moreover, based on their location in terms of cardinal directions seen from the city center, the sampled trees were divided into the groups center (numbers 8-11, 14), northern (numbers 1, 2, 6, 7), eastern (numbers 12, 13, 15, 16) and western (numbers 3-5) growing trees. The sampling locations differed also in terms of ground water availability. Phi and Strokova (2015) analyzed the ground-water level in Hanoi and found high water levels northern of the Red river for sampling locations 1, 2, 6 and 7 as well as for the sampling spots 3, 4 and 5. In the inner city center (locations $8,9)$ the ground-water level is very deep, however increasing towards the Red river and at the southern and western parts of the city (Phi and Strokova 2015).

Data collection included increment core collection, recording of tree structural data such as diameter at breast height $(d b h)$, tree height $(h)$, height to the crown base $(c b)$, crown radii in four cardinal directions (North, East, South, West) following basic forestry inventory methods (Pretzsch 2010) and prevalent site conditions including tree position (coordinates and altitude).

Based on these collected tree data, the quadratic mean crown radius $(c r)$ and crown projection area $(c p a)$ were calculated as following

$$
\mathrm{cr}=\sqrt{\left(r_{\mathrm{N}}^{2}+r_{\mathrm{S}}^{2}+\ldots+r_{\mathrm{W}}^{2}\right) / 4}
$$

with $r_{\mathrm{N}}$ as the widest measured crown extension in the northern direction,..., $r_{\mathrm{W}}$ the widest crown extension in the western direction.

$$
c p a=c r^{2} \times \pi
$$

with $\mathrm{cr}$ as the crown radius and $\pi$ as pi.

Increment core collection was conducted at each tree with extraction of two wooden cores in opposing directions (north, east) at a height of $1.3 \mathrm{~m}$ aimed at the center of the tree. The increment corer was $5 \mathrm{~mm}$ in diameter (Manufacturer: Haglöf, Sweden).

\section{Core and data processing}

All cores were mounted on grooved boards with glue and sanded using progressively finer sand papers. The first sanding was applied to flatten the cores, whereas the subsequent sanding episodes polished the cores for better visualization of the cross-sectional area (Speer 2012). The 


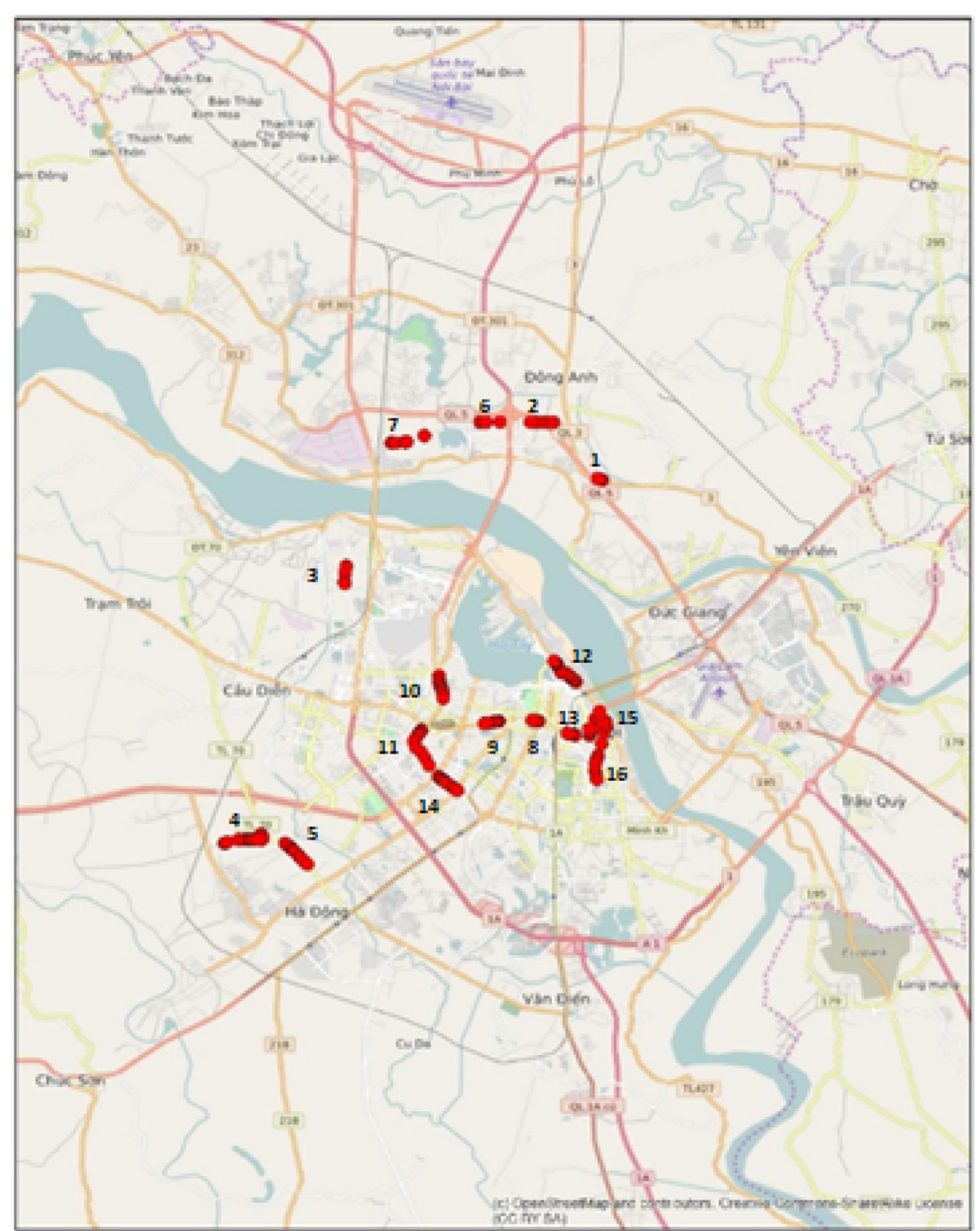

Fig. 2 Selection of African mahogany (K. senegalensis) in Hanoi, Vietnam with numbers indicating categories urban, suburban and rural as well as cardinal direction north, east, west and center

annual tree-ring widths of the cores were measured using a Lintab digital positioning table with a resolution of $1 /$ $100 \mathrm{~mm}$ (Rinn 2005). For cross-dating of the time-series, the software package TSAP-Win (Rinn 2003) was used and hereby checked for possible missing growth rings or measurement errors. Further analyses were carried out in $R$ ( $R$ Core Team 2018) using package dplR (Bunn et al. 2015). With dplR, all tree-ring series were indexed using a double detrending process: first, modified negative exponential curves were applied followed by cubic smoothing splines (20 years rigidity, 50\% wavelength cutoff). The detrending was conducted to remove low frequency trends, which are age associated (Holmes et al. 1986; Gillner et al. 2014). The resulting detrended series were averaged using
Tukey's biweight robust mean to build a final chronology and chronologies for each category (all trees; urban, suburban, rural; center, north, east, west). As a result of detrending, standardized chronologies with a yearly ring width index (RWI) averaging around 1 were obtained. Values smaller than 1 indicate growth below normal, while values greater than 1 indicate growth higher than normal. For chronology building, the autocorrelation of every individual series was removed (maximum order: 3 ). This procedure of detrending ensured a removal of all long-term growth trends, thereby obtaining a chronology containing only tree ring variability with climate fluctuations (Cook and Holmes 1986; Gillner et al. 2013). The statistical validity of the chronologies was assessed using the expressed 
Table 1 Information on sampling site, urbanity grade classification, cardinal direction of sampling site and ground water level of the sampled African mahogany (Khaya senegalensis) trees in Hanoi

\begin{tabular}{|c|c|c|c|c|c|}
\hline No. & Name of site & No. of trees & Urbanity grade & Cardinal direction & Ground water level \\
\hline 1 & Dong Ang & 18 & rural & North & high \\
\hline 2 & Dong Ang & 5 & rural & North & high \\
\hline 3 & Dan Phuong & 4 & rural & West & high \\
\hline 4 & Hoai Duc & 12 & rural & West & high \\
\hline 5 & Hoai Duc & 13 & rural & West & high \\
\hline 6 & Dong Ang & 5 & rual & North & high \\
\hline 7 & Dong Ang & 11 & suburban & North & high \\
\hline 8 & City center & 5 & urban & Center & low \\
\hline 9 & Clty center & 10 & suburban & Center & low \\
\hline 10 & City center & 11 & suburban & Center & low \\
\hline 11 & City center & 11 & suburban & Center & low \\
\hline 12 & City center & 9 & urban & East & high \\
\hline 13 & City center & 11 & urban & East & high \\
\hline 14 & City center & 5 & urban & Center & low \\
\hline 15 & City center & 15 & urban & East & high \\
\hline 16 & City center & 14 & urban & East & high \\
\hline
\end{tabular}

${ }^{\mathrm{a}}$ Based on Phi and Strokova (2015)

population signal (EPS) for the common period of the time series of all analyzed tree individuals.

\section{Trend analysis (long term trends)}

Using the R package lme4 (Bates et al. 2015), three linear mixed models of the following forms 4, 5 and 6 were developed to assess the influence of the tree age (age), the time of growth (before 1960/since 1960; time of growth), urbanity (urban/rural; grade of urbanity) and further climate $(M)$ on the annual basal area (response variable) derived by increment cores.

To assess the climate influence on tree growth, we calculated the index of de Martonne (1926) M on the basis of the precipitation (in $\mathrm{mm}$ ) and mean temperature (in ${ }^{\circ}$ C) for each month from 1970 to 2012:

$$
M=\operatorname{Prec} /\left(\text { Temp }_{\text {mean }}+10\right)
$$

with $M$ as the de Martonne index, Prec as precipitation in $\mathrm{mm}$ and $\mathrm{Temp} p_{\text {mean }}$ as mean temperature in ${ }^{\circ} \mathrm{C}$.

$$
\begin{aligned}
\log \left(b a_{i j}\right)=a_{0} & +a_{1} \times \text { time of } \text { growth }_{i j}+\left(b_{0}+b_{1}\right. \\
& \left.\times \text { time of } \text { growth }_{i j}\right) \times \log \left(\text { age }_{i j}\right)+c_{i j} \\
& +\varepsilon_{i j},
\end{aligned}
$$

with $b a_{i j}$ as the basal area for the $j$ th of $n_{i}$ observations, $a_{0}$ as the intercept, $a_{1}$ as the intercept of time of growth $h_{i j}$, time of growth $_{i j}$ as the growth periods before 1960 or since 1960, $b_{0}$ as fixed effect, $b_{1}$ as fixed effect of time of growth $_{i j}$, age $e_{i j}$ as the age of each tree, $c_{i j}$ as random effects and $\varepsilon_{i j}$ as errors.

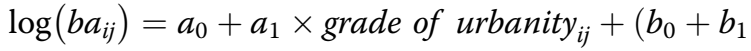

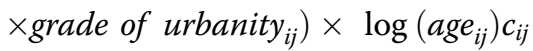

$$
\begin{aligned}
& +\varepsilon_{i j},
\end{aligned}
$$

with $b a_{i j}$ as the basal area for the $j$ th of $n_{i}$ observations, $a_{0}$ as the intercept, $a_{1}$ as the intercept of grade of urbanity ${ }_{i j}$, grade of urbanity $_{i j}$ as urban or rural, $b_{0}$ as fixed effect, $b_{1}$ as fixed effect of grade of urbanity ${ }_{i j}$, age $e_{i j}$ as the age of each tree, $c_{i j}$ as random effects and $\varepsilon_{i j}$ as errors.

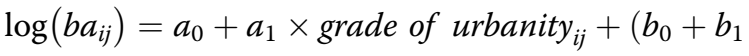

$$
\begin{aligned}
& \left.\times \text { grade of urbanity }_{i j}\right) \times \log \left(\text { age }_{i j}\right) \\
& +\left(b_{0}+b_{1} \times \text { grade of urbanity }{ }_{i j}\right) \\
& \times \log \left(M_{i j}\right)+c_{i j}+\varepsilon_{i j}
\end{aligned}
$$

with $b a_{i j}$ as the basal area for the $j t h$ of $n_{i}$ observations, $a_{0}$ as the intercept, $a_{1}$ as the intercept of grade of urbanity $_{i j}$, grade of urbanity ${ }_{i j}$ as urban or rural, $b_{0}$ as fixed effect, $b_{1}$ as fixed effect of grade of urbanity ${ }_{i j}$, age $i j$ as the 
age of each tree, $M_{i J}$ as the de Martonne index, $c_{i j}$ as random effects and $\boldsymbol{i} \boldsymbol{j}$ as errors.

To summarize the variables of the equations, $\boldsymbol{a}_{1}, \ldots$, $\boldsymbol{a}_{n}$ and, $\boldsymbol{b}_{1}, \ldots, \boldsymbol{b}_{n}$ are the fixed effects with the " $a$ " parameters are components of the intercept and the " $b$ " parameters are components of the slope, respectively. The two dummy variables time of growth and grade of urbanity were introduced to differentiate between the two growth-trend relevant periods (before 1960/since 1960) and urbanity classifications (urban/rural). If $a_{1}$ in eq. 4 differed significantly from 0 , this would mean that the age-basal area relationship before 1960 had a different intercept than since 1960. In eq. 5 this would indicate that the intercept of urban trees is not the same as for rural trees. The parameter $b_{1}$ in both equations has an analogous meaning for the slope. The " $c$ " parameters are random effects, which are assumed to be normally distributed. These random effects cover statistical dependencies which are due to the nested data structure. The errors $\boldsymbol{i} \boldsymbol{j}$ are assumed to be independent identically distributed.

\section{Results}

In Table 2 the measured characteristics of all analyzed trees are presented with found minimum, maximum and average measured values together with standard deviation. The average age of all sampled trees was 33 years with a minimum of 10 years and a maximum of 73 years. The smallest African mahogany had a $d b h$ of $44.1 \mathrm{~cm}$, while the largest tree had a $d b h$ of $123.1 \mathrm{~cm}$ and the average $d b h$ was $73.4 \mathrm{~cm}$ with $16.0 \mathrm{~cm}$ standard deviation for all trees. The average height of African mahogany was $22.6 \mathrm{~m}$ (14.1 $\mathrm{m}$ minimum and $36.0 \mathrm{~m}$ maximum). Further, the average yearly growth rate was $5.9 \mathrm{~mm}$.

Figure 3 displays the average undetrended radius increment, basal area increment and age-detrended growth of African mahoganys in Hanoi, Vietnam from 1947 to 2012. The first order autocorrelation was 0.3 and the resulting detrended chronology of all trees (Fig. 3c) had an EPS value of 0.64 .

Overall, the analyzed trees showed a very steady growth increase, as in particular the BAI displays. There were no exceptionally good and bad growth years in the last years, 2010, 1998 and 1994 are examples of years with growth above the average, while 1992, 1997 and 1999 were years with growth below the average.

\section{Trends in relation to the growing site}

In a next step, the growth over the past years was analyzed regarding the growing site in a finer scale (urban, suburban, rural). Overall tree structures, growth and age varied depending on growing location (Table 3). Age, $d b h$, tree height, crown radius, crown length and cpa of urban trees were in average greater than of suburban and rural trees. EPS values of all three chronologies were lower than 0.85 (Wigley et al. 1984). The autocorrelation before the detrending process was highest for the suburban chronology and lowest for the rural chronology.

The radius increment, basal area growth and ring width index (RWI) of rural, urban and suburban trees displayed clear differences (Fig. 4). While the radius increment and the basal area increment of rural trees showed a higher growth rate than urban and suburban trees, the indexed growth values were more uniform. Though between 2002 and 2007, rural trees displayed greater RWI as well, albeit the growth of suburban and urban trees was more enhanced from 2010 on.

To further analyze the growth of African mahogany in Hanoi, sampled trees were classified based on the cardinal direction (seen from the city center) in which they were found. Table 4 displays the tree characteristics of trees based on this classification. Center and east growing trees showed greatest tree structures, while northern trees were youngest and had smallest tree structures. EPS values of all four chronologies were lower than 0.85 with highest values for the eastern chronology and lowest values for the center chronology of African mahogany. Moreover, autocorrelation of the undetrended chronologies varied between 0.22 for the northern trees and 0.37 for the center trees.

Figure 5 displays the radius increment, basal area growth and indexed ring width values of African mahogany trees based on the cardinal direction they were growing. Radius increment and basal area highlight a better growth of northern trees with smallest growth in the center and eastern region. Ring width index RWI, however, shows an acceleration of the center and eastern trees during the more recent years.

Table 2 Minimum, average, maximum and standard deviation (SD) of age, diameter at breast height (dbh), radius increment (RI), tree height $(h)$, crown radius ( $c r)$, crown length and crown projection area (cpa) of the analyzed African mahogany (Khaya senegalensis) trees in Hanoi

\begin{tabular}{|c|c|c|c|c|c|c|c|}
\hline & Age & $d b h(\mathrm{~cm})$ & $R /(\mathrm{mm})$ & $h(\mathrm{~m})$ & $\mathrm{cr}(\mathrm{m})$ & Crown length (m) & $c p a\left(\mathrm{~m}^{2}\right)$ \\
\hline Min & 10.0 & 44.1 & 0.2 & 14.1 & 3.1 & 9.1 & 29.3 \\
\hline Avg & 33.3 & 73.4 & 5.9 & 22.6 & 6.5 & 16.9 & 141.1 \\
\hline Max & 73.0 & 123.1 & 46.9 & 36.0 & 11.6 & 27.0 & 424.7 \\
\hline SD & 13.5 & 16.0 & 5.8 & 5.1 & 1.7 & 4.3 & 77.6 \\
\hline
\end{tabular}




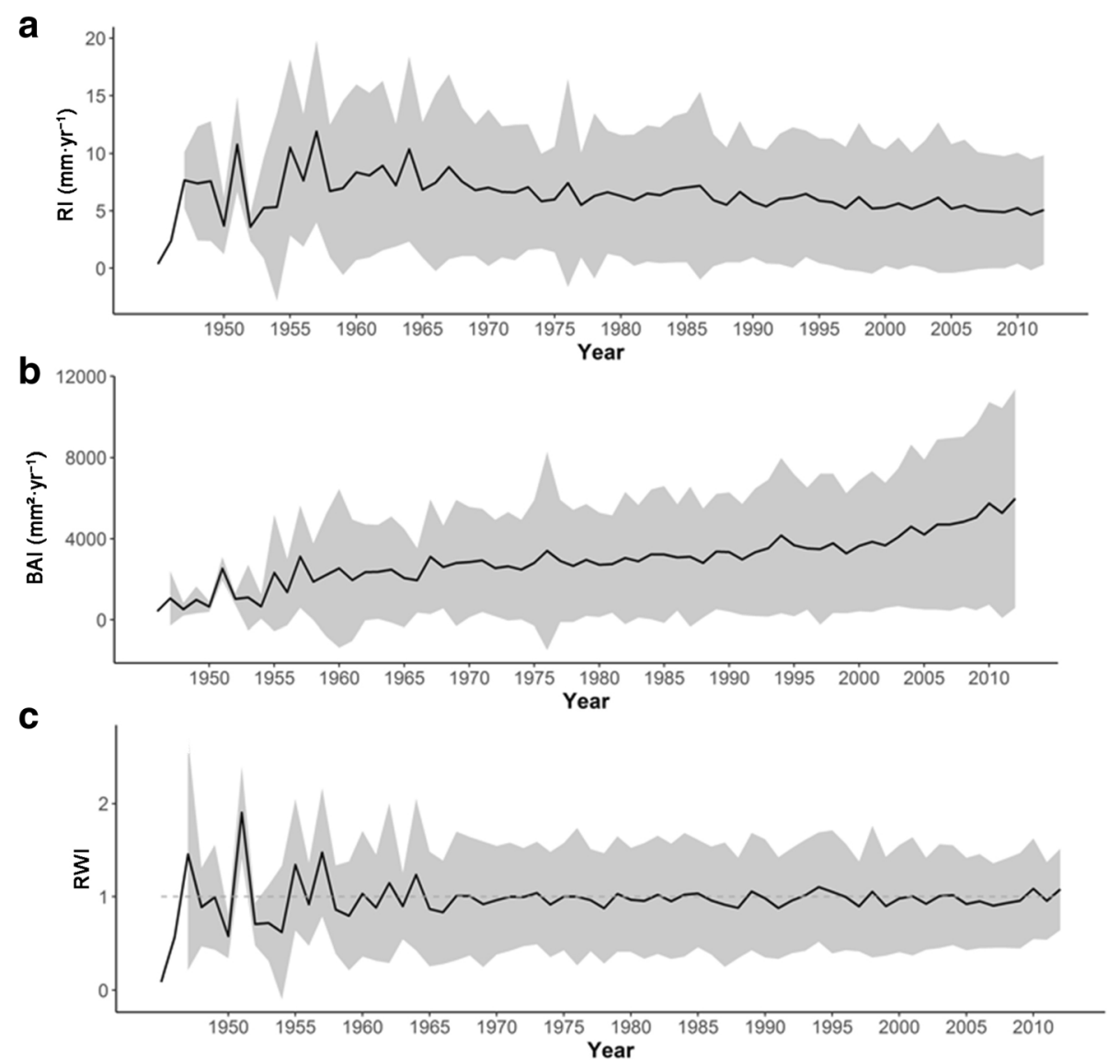

Fig. 3 Radius increment (a), basal area increment (b) and detrended ring width index (c) of all sampled African mahogany trees (K. senegalensis) in Hanoi with according standard deviation (grey areas)

\section{Long-term growth trends}

Figure 6 displays the growth of African mahogany in Hanoi in comparison to the averaged growth of urban trees in 10 metropolises worldwide from the study of Pretzsch et al. (2017). When analyzing the growth trends from 1960 to 2012 and before 1960, a similar growth of African mahogany in these two periods was found. The growth of African mahogany was similar regardless of the time of growth, only minor differences were found (Fig. 6a, colored lines). Furthermore, rural African mahogany trees were growing better than trees in rural areas. Only very young urban trees grew slightly better than rural trees (Fig. 6b, colored lines).

The results of the statistical models in Fig. 6 are presented in Table 5 ( $\mathrm{a}$ and $\mathrm{b}$ ). A lower AIC value of the model in Table $5 \mathrm{~b}$ indicates a better fit compared to the model presented in Table $5 \mathrm{a}$. In both models, age positively influences growth, therefore as also illustrated in Fig. 6 older African mahogany trees in Hanoi tend to be greater in size than younger trees. Time of growth was negatively correlated with growth, however together with age this effect was reversed. Urbanity classification (urban

Table 3 Number and average with standard deviation of age, diameter at breast height (dbh), tree height (h), crown radius (cr), crown length and crown projection area ( $c p a)$ as well as the Expressed Population Signal (EPS) and the Autocorrelation (AR) of the analyzed African mahogany (K. senegalensis) in Hanoi in the categories urban, suburban and rural

\begin{tabular}{|c|c|c|c|c|c|c|c|c|c|}
\hline & $n$ & Age(a) & $d b h(\mathrm{~m}]$ & $h(\mathrm{~m})$ & $\operatorname{cr}(\mathrm{m})$ & Crown length(m) & $c p a\left(m^{2}\right)$ & EPS $^{a}$ & $A R$ \\
\hline urban & 37 & $40.5 \pm 12.7$ & $82.2 \pm 9.7$ & $26.8 \pm 4.3$ & $7.3 \pm 2.1$ & $20.1 \pm 4.1$ & $179.3 \pm 98.1$ & 0.73 & 0.31 \\
\hline suburban & 48 & $39.0 \pm 10.6$ & $76.4 \pm 9.7$ & $22.9 \pm 3.4$ & $6.0 \pm 1.5$ & $16.8 \pm 3.5$ & $120.2 \pm 65.8$ & 0.4 & 0.39 \\
\hline rural & 57 & $22.5 \pm 8.5$ & $62.9 \pm 12.0$ & $18.4 \pm 2.6$ & $6.1 \pm 1.1$ & $14.0 \pm 2.4$ & $121.7 \pm 45.3$ & 0.8 & 0.21 \\
\hline
\end{tabular}

${ }^{\mathrm{a}}$ Based on the ring width index of tree ring chronologies for the common period, obtained by double detrending of the tree ring series 


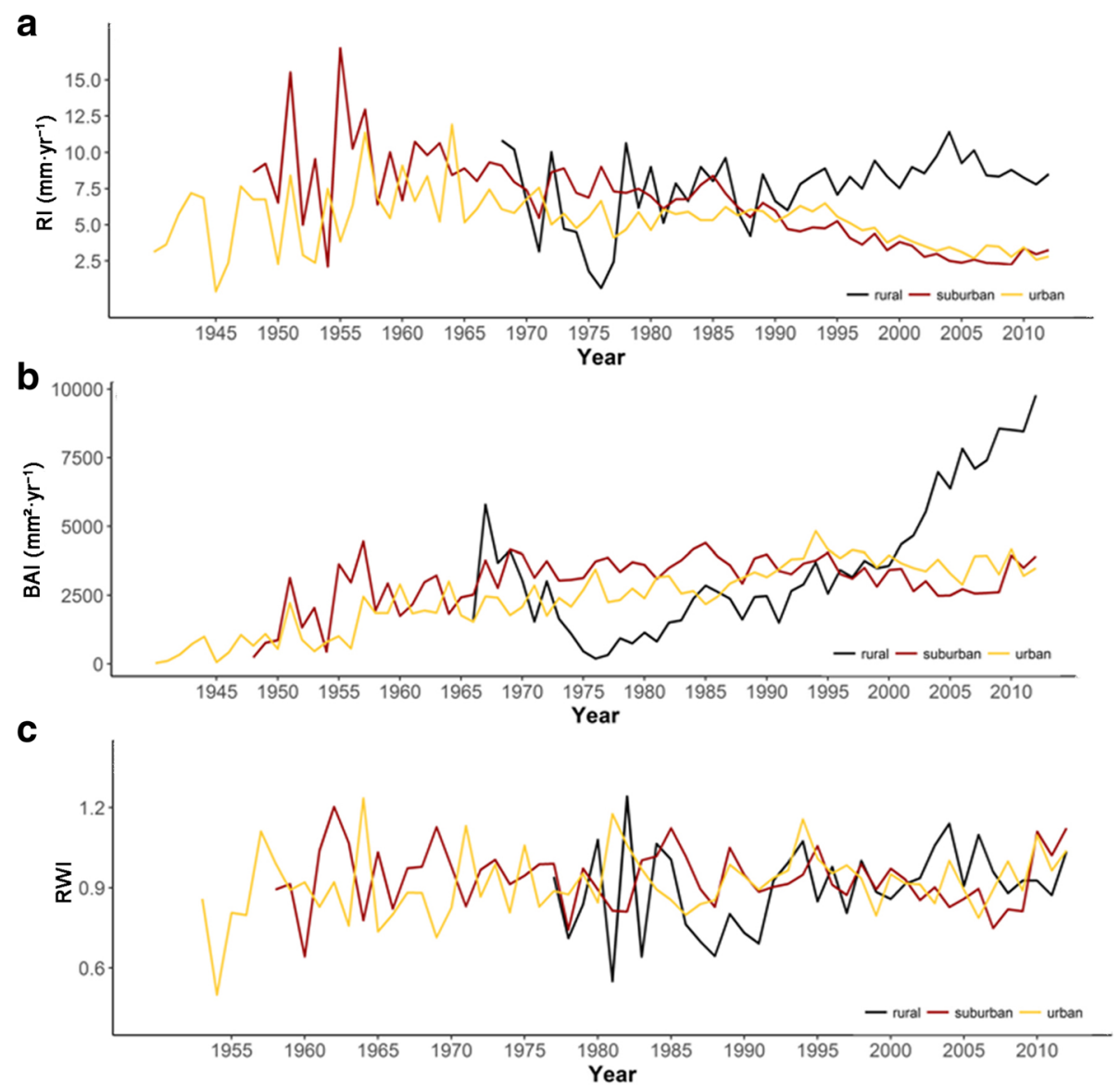

Fig. 4 Radius increment (a), basal area increment (b) and ring width index RWI (c) of African mahogany (K. senegalensis) in Hanoi growing at forest, rural, suburban and urban sites

to rural) had the strongest effect on the growth rate, with rural trees showing higher basal area growth than urban trees, however during very young age this effect was reversed.

\section{Climate-growth relationships}

The influence of climate, i.e. water supply as the index of de Martonne on growth in relation to the grade of urbanity and growing direction were further tested (Table 6). A mixed model revealed a positive influence of more favorable water status on growth, albeit the relationship was not significant. In interaction with the grade of urbanity, a better climate had negative influences on urban tree growth. However the effect size was small and not significant.

The found effects were also revealed in a finer scaling of urbanity (urban, suburban, rural), with suburban tree growth displaying similar correlations with climate as was shown above for urban trees. The growing site in terms of cardinal direction had no significant influence on tree growth and interactions with climate were also non-significant.

Table 4 Number and average with standard deviation of age, diameter at breast height (dbh), tree height (h), crown radius (cr), crown length and crown projection area (cpa) as well as the Expressed Population Signal (EPS) and Autocorrelation (AR) of the analyzed African mahogany (K. senegalensis) in Hanoi based on cardinal direction of sampling site (north, center, east, west)

\begin{tabular}{llllllllll}
\hline & $n$ & Age $(\mathrm{a})$ & $d b h(\mathrm{~m})$ & $h(\mathrm{~m})$ & $c r(\mathrm{~m})$ & Crown length $(\mathrm{m})$ & $c p a\left(m^{2}\right)$ & $E^{\mathrm{a}}$ & $\mathrm{AC}^{\mathrm{a}}$ \\
\hline North & 35 & $22.9 \pm 12.1$ & $60.2 \pm 10.5$ & $18.1 \pm 2.5$ & $5.5 \pm 0.8$ & $13.6 \pm 2.0$ & $98.6 \pm 28.9$ & 0.71 & 0.22 \\
Center & 44 & $38.6 \pm 10.1$ & $80.0 \pm 14.7$ & $24.9 \pm 4.6$ & $6.2 \pm 1.7$ & $18.3 \pm 4.5$ & $130.7 \pm 70.0$ & 0.50 & 0.37 \\
East & 41 & $41.1 \pm 13.3$ & $78.9 \pm 14.3$ & $26.8 \pm 3.9$ & $7.2 \pm 2.1$ & $20.1 \pm 3.8$ & $177.2 \pm 102.1$ & 0.72 & 0.31 \\
West & 40 & $30.0 \pm 10.1$ & $71.6 \pm 13.1$ & $20.0 \pm 2.8$ & $6.5 \pm 1.2$ & $15.2 \pm 2.6$ & $138.8 \pm 49.0$ & 0.60 & 0.29 \\
\hline
\end{tabular}

${ }^{\mathrm{a}}$ Based on the ring width index of tree ring chronologies for the common period, obtained by double detrending of the tree ring series 


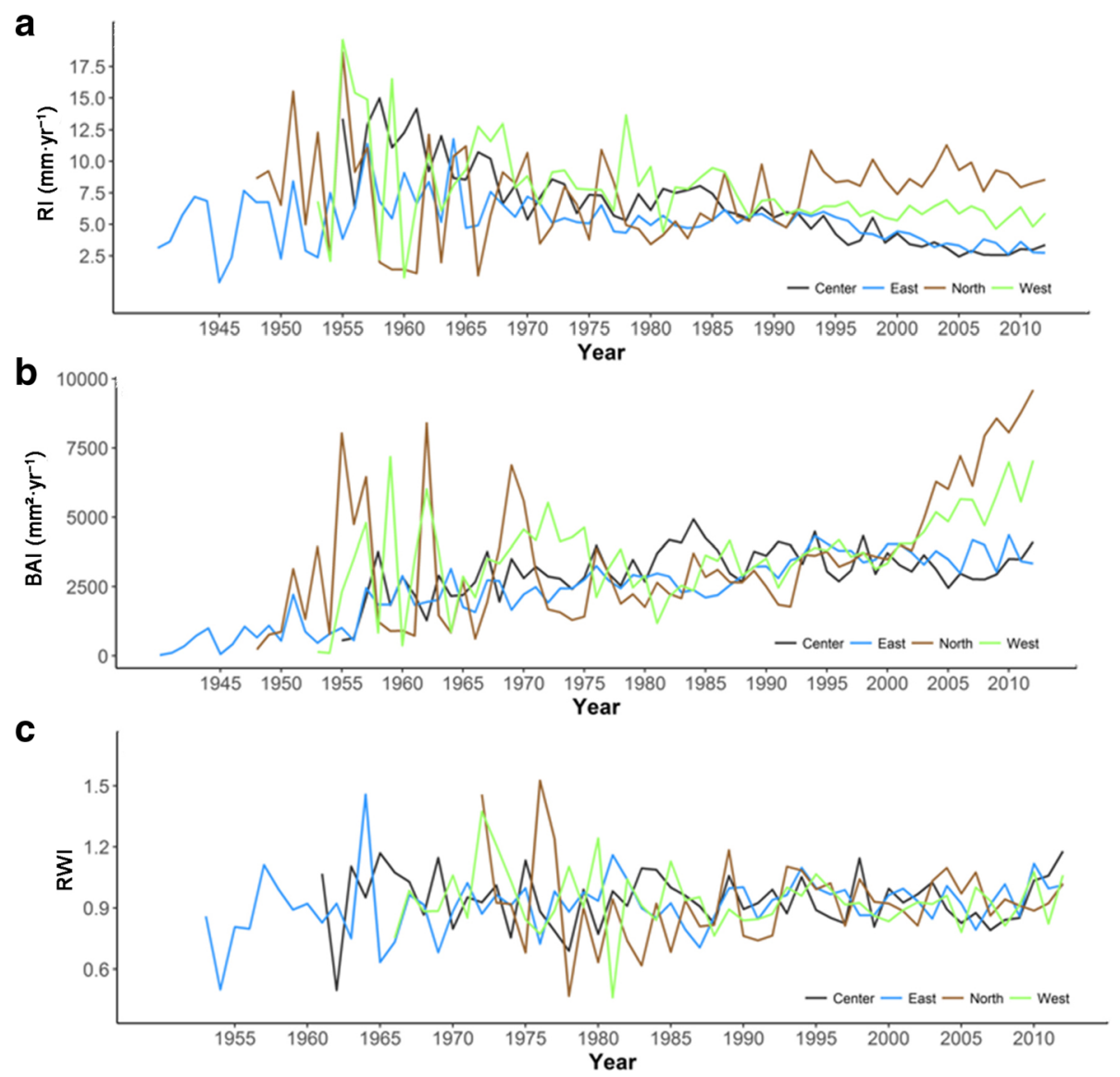

Fig. 5 Radius increment (a), basal area increment (b) and ring width index RWI (c) of African mahogany (K. senegalensis) in Hanoi growing in the center, in eastern, northern and western direction

\section{Discussion}

\section{Growth of $K$. senegalensis}

The growth potential of the studied African mahogany is hardly known, due to a lack of long-term experimental plots, physiological and dendrochronological studies of this species (Arndt et al. 2015). The scarcity of dendrochronological studies might also be related to the difficulties of tree ring distinction of African mahogany. Tarhule and Hughes (2002) even classified mahogany as a problematic species for dendrochronological approaches
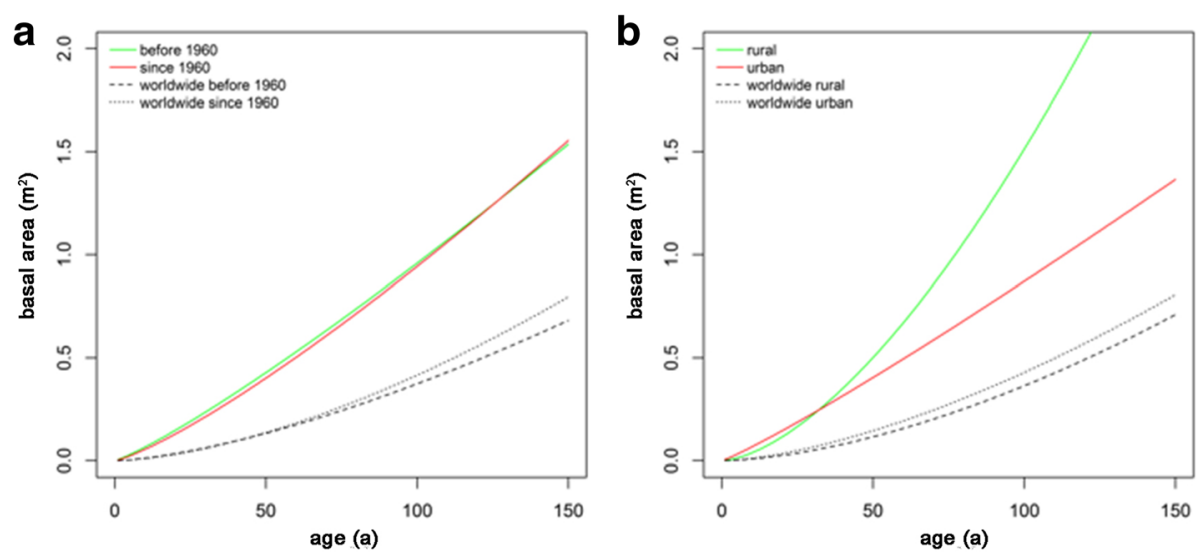

Fig. 6 The size growth in terms of basal area growth of K. senegalensis in Hanoi and the worldwide found growth trends of Pretzsch et al. (2017) for (a) the period before 1960 compared to the period since 1960 and (b) urban trees compared to more rural growing trees 
Table 5 (a) Linear mixed model on the annual basal area increment $\left(\mathrm{mm}^{2} \cdot \mathrm{yr}^{-1}\right.$ ) of all analyzed trees (response variable) with the individual tree code as random effect and fixed effects logarithmized age related to the factor time of growth (period before 1960 and period since 1960), SD: Standard deviation, AIC: Akaike Information Criterion

\begin{tabular}{|c|c|c|c|}
\hline Parameter & Fixed effect & Value \pm SE & $p$ \\
\hline $\bar{a}$ & Intercept & $-5.40 \pm 0.14$ & $<0.001$ \\
\hline $\log \left(a g e_{i j}\right)$ & Age & $1.16 \pm 0.04$ & $<0.001$ \\
\hline time of growth & Time of growth & $-0.34 \pm 0.13$ & 0.01 \\
\hline$b \times$ time of growth ${ }_{i j} \times \log \left(a g e_{i j}\right)$ & Age $\times$ Time of growth & $0.07 \pm 0.04$ & 0.06 \\
\hline Random effect $d_{i j}$ & & 0.47 & - \\
\hline$\varepsilon$ & & 0.19 & - \\
\hline $\mathrm{AIC}$ & & -1664.82 & - \\
\hline
\end{tabular}

Levels of Time of growth: 2 (Before 1960 and Since 1960)

because of unclear tree ring formation. The low EPS values of the presented chronologies confirm these problems in wood core analyses of African mahogany. The EPS values were mostly lower than the threshold of 0.85 for dendrochronological analyses set by Wigley et al. (1984). However, the studied African mahogany trees were in average only 30 years old, which increases difficulties in chronology building due to the low number of rings (Speer 2012). Moreover the selected trees cover a wide variety of conditions in terms of the grade of urbanity, water supply and other urban settings (pit size, pollutant input) affecting tree ring formation, which also makes chronology building more difficult (Speer 2012; Moser et al. 2016b; Campelo et al. 2018; Vieira et al. 2018).

We calculated annual stem radius growth rates of around $6 \mathrm{~mm}$ on average for African mahogany in Hanoi. Perera et al. (2012) analyzed the growth rate of three mahogany specimen and found similar growth rates of around 3-8 $\mathrm{mm}$ per year. However, in comparison with other urban tree species studied (e.g. Gillner et al. (2014), Dahlhausen et al. (2016), Moser et al. (2017)) this growth rate is exceptionally high. Pretzsch et al. (2017) for example found in their worldwide metropolis study of urban trees average stem radius growth rates of $3.2 \mathrm{~mm}$ per year. These high growth rates, especially in a stressful environment such as urban areas might be due to the high resilience against drought and heat stress, as Arndt et al. (2015) found out for this species.

\section{Influence of site conditions and the city climate on tree growth}

An analysis of the growth of African mahogany in Hanoi showed a distinctly better undetrended growth and basal area increment of rural trees in comparison to suburban and urban tree. However, the current higher growth rate of rural trees can also be influenced by the younger age of trees growing in the rural surroundings of Hanoi, since younger trees mostly exhibit higher growth rates than older trees (Esper et al. 2002). The studied rural trees were on average around 25 years younger than the urban trees, followed by a markedly smaller $d b h$ of urban trees compared to suburban and urban trees. This was confirmed by a more uniform growth of urban, rural and suburban trees after agetrend removal. Nevertheless, rural trees were marked by a very high basal area increment compared to urban and suburban trees, exceeding the growth of urban and suburban trees at a similar age by far. Possible reasons for this high basal area increment of rural trees can be a better water supply by a high ground-water level (Phi and Strokova 2015) and lower pollution inputs (Kim Oanh et al. 2006).

Table 5 (b) Linear mixed model on the annual basal area increment $\left(\mathrm{mm}^{2} \cdot \mathrm{yr}^{-1}\right.$ ) of all analyzed trees (response variable) with the individual tree code as random effect and fixed effects logarithmized age related to the growing site (urban and rural), SD: Standard deviation, AIC: Akaike Information Criterion

\begin{tabular}{|c|c|c|c|}
\hline Parameter & Fixed effect & Value \pm SE & $p$ \\
\hline $\bar{a}$ & Intercept & $-6.92 \pm 0.08$ & $<0.001$ \\
\hline $\log \left(a g e_{i j}\right)$ & Age & $1.59 \pm 0.02$ & $<0.001$ \\
\hline urbanity grade $_{i j}$ & Grade of urbanity & $1.68 \pm 0.10$ & $<0.001$ \\
\hline$b \times$ urbanity $\operatorname{grade}_{i j} \times \log \left(\right.$ age $\left._{i j}\right)$ & Age $\times$ Grade of urbanity & $-0.48 \pm 0.02$ & $<0.001$ \\
\hline Random effect $d_{i j}$ & & 0.52 & - \\
\hline$\varepsilon$ & & 0.17 & - \\
\hline AIC & & -2356.13 & - \\
\hline
\end{tabular}

Levels of Urbanity: 2 (Urban and Rural) 
Table 6 Linear mixed model on the annual basal area growth $\left(\mathrm{mm}^{2} \cdot \mathrm{yr}^{-1}\right)$ of all analyzed trees (response variable) with the individual tree code as random effect and fixed effects growing site (urban and rural) and the de Martonne index with interactions, SD: Standard deviation, AIC: Akakike Information Criterion

\begin{tabular}{|c|c|c|c|}
\hline Parameter & Fixed effect & Value \pm SE & $p$ \\
\hline $\bar{A}$ & Intercept & $-7.14 \pm 0.16$ & $<0.001$ \\
\hline $\log (a g e)$ & Age & $1.61 \pm 0.01$ & $<0.001$ \\
\hline Urbanity grade $_{i j}$ & Grade of Urbanity & $1.89 \pm 0.19$ & $<0.001$ \\
\hline $\log \left(M_{i j}\right)$ & De Martonne Index & $0.04 \pm 0.03$ & 0.27 \\
\hline$b \times \log ($ urbanity grade $) \times \log ($ age $)$ & Grade of Urbanity $\times$ Age & $-0.50 \pm 0.02$ & $<0.001$ \\
\hline$b \times$ urbanity grade ${ }_{i j} \times \log \left(M_{i j}\right)$ & Grade of Urbanity x de Martonne Index & $-0.03 \pm 0.04$ & 0.38 \\
\hline Random effect $d_{i j}$ & & 0.52 & - \\
\hline$\varepsilon$ & & 0.17 & - \\
\hline AIC & & -2451.83 & - \\
\hline
\end{tabular}

Levels of Urbanity: 2 (Urban and Rural)

Further analyses of African mahogany growth revealed a better development of trees located in the northern areas of Hanoi than of trees studied in other directions. In particular trees in the center and in eastern regions showed far less growth rates than western and northern trees. These findings might be influenced by higher humidity and moisture in the north due to the fact the "Red River" crosses city from the north to the east. Results of Phi and Strokova (2015) describe a lower ground water level in the city center of Hanoi compared to the northern, eastern and western parts of the city, confirming this assumption. However, trees of eastern region did not show an enhanced growth. This can be attributed to the study design of African Mahogany trees, since trees in the northern region were also mostly rural trees and eastern trees were all urban trees. Therefore the underlying trend was probably also influenced by the urbanity classification.

Long-term growth trends and climate-growth relationships Findings in forests of different climate zones (Fang et al. 2014; Kauppi et al. 2014; Pretzsch et al. 2014) and in cities worldwide (Searle et al. 2012; Pretzsch et al. 2017) illustrate accelerated growth rates of trees in recent decades as well as a better growth of urban trees in city centers compared to rural trees. These findings raise the question of tree responses in forests and cities to climate change and changed environmental conditions. Due to the urban heat island effect (Oke 1987; Coburn 2009), urban areas might reflect future conditions induced by climate change and the resulting consequences for trees (Bussotti et al. 2014; Farrell et al. 2015). For example, the study of Pretzsch et al. (2018) showed that forest trees can grow faster by climate change, but the annually growing wood has gradually becoming lighter, by up to eight to $12 \%$ since 1900 . The causes might be temperature increased and prolonged vegetation periods caused by climate change as well as nitrogen inputs by agriculture, traffic and industry
(Pretzsch et al. 2018). This effect of lighter wood might be even stronger in case of urban trees. Lighter wood is less solid, it has a lower calorific value and lower contribution to carbon sequestration. Less solid wood in living trees also increases the risk of damage events such as breakage due to wind or snow, which is of high importance in urban areas.

In fact, the worldwide study of Pretzsch et al. (2017) on 10 urban tree species include analyses of boreal, temperate, Mediterranean, and subtropical climate conditions and revealed that across all climate zones urban tree growth has significantly enhanced during the past decades. On average trees in the city centers also grew significantly quicker than trees in the city's rural surrounding (Pretzsch et al. 2017). Possible reasons for this trend are based on the global climate change leading to higher temperatures (IPCC 2014) with higher $\mathrm{N}$-deposition rates and higher $\mathrm{CO}_{2}$ concentrations (Churkina et al. 2010) along with prolonged growing seasons (Chmielewski and Rötzer 2001).

In contrast to the results found for other urban tree species in cities worldwide (Searle et al. 2012; Pretzsch et al. 2017) no accelerated basal area growth was found over time for African mahogany in Hanoi. Moreover, contrary to the observed worldwide trend, mahogany trees growing in urban settings showed smaller basal area growth than rural trees. Rural African mahogany trees with age over 30 years grew significantly better than urban trees. Very young aged urban trees, however, displayed better basal area growth than rural trees. Due to the age differences, though, the agedetrended RWI results can provide further insight to the growth of urban and rural African mahogany trees in Hanoi. Here, similar growth rates were found, when analyzing the age detrended RWI development of urban and rural trees, though, rural trees showed low-growth episodes (1985-1992, 2009-2012) compared to urban trees. 
Having a closer look at the results of Pretzsch et al. (2017) slightly different results can be derived when urban trees of the subtropical climate are compared to the worldwide average: Subtropical rural trees showed a very high growth acceleration since 1960. Whether a tree in the city centers grew better compared to trees in the rural surrounding is highly dependent on the city analyzed. Moser et al. (2017) showed a trend of better urban growth in recent years for trees in the city of Houston, Texas, a subtropical city. The contrasting results found for the subtropical city of Hanoi might also be due to the critical effects of climate change in Vietnam (IPCC 2001; Schmidt-Thomé et al. 2015), but also high air pollution (Kim Oanh et al. 2006) and low ground-water levels in the city center (Phi and Strokova 2015).

Using a mixed model approach a positive though not significant influence of climate on tree growth in Hanoi was found. Moreover, urban trees showed less growth with better climate conditions (higher de Martonne-Index), albeit this correlation was also not significant. As discussed before, the negative influences of the urban environment in Hanoi (low ground water level, high air pollution) counteract positive influences affecting trees in urban areas such as higher temperatures (IPCC 2014) and a longer growing season (Chmielewski and Rötzer 2001).

This study illustrates that the relationships of tree growth in urban and rural areas is a complex interaction of factors such as urbanity grade, planting age and design as well as climate variables (e.g. city location with according climate, climate change effects, pollution). More studies are necessary to understand worldwide urban tree growth, in particular under conditions changed by climate change.

\section{Conclusion}

Vietnam and in particular Hanoi will be affected most severely by climate change. Urban trees such as the here studied urban tree species African mahogany can mitigate the negative effects of climate change and the urban heat island effect, e.g., through shading and cooling. However, African mahogany trees in the city center of Hanoi showed less growth than rural trees. This might be due to changing environmental conditions, however more likely is a worse water supply by a lower ground -water level and higher pollution loads. Rural trees were significantly younger and displayed higher growth rates, in particular basal area growth in recent years was enhanced. Since the climate mitigation services trees can provide are highly related to tree vitality and growth, the living conditions of urban trees in cities like Hanoi need to be improved provide sustainable ecosystem services for better human living conditions, especially in urban regions highly affected by global warming.

\section{Abbreviations}

AIC: Akaike information criterion " AR: Autocorrelation " BAI: Basal area increment; cb: Height to crown base; cpa: Crown projection area;

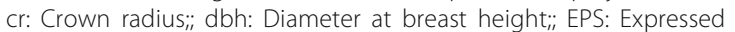
population signal; : Tree height; M: de Martonne index;" Rl: Radius increment; RWI: Ring width index; SD: Standard deviation; urb: Urbanity.

\section{Acknowledgements \\ Thanks to the AUDI Environmental Foundation for funding this study (project 5101954: "Reaktionskinetik von Bäumen unter Klimaveränderungen" - "Reaction kinetics of trees under climate change"). All contributors thank the municipal authority of Hanoi/Nietnam for supporting the search for the trees and the allowance of measuring and coring the trees.}

\section{Funding}

Funding Source: AUDI Environmental Foundation (project 5101954: "Reaktionskinetik von Bäumen unter Klimaveränderungen" - "Reaction kinetics of trees under climate change").

\section{Availability of data and materials}

The materials described in the manuscript including all relevant raw data will be freely available upon request from the corresponding author.

\section{Authors' contributions \\ $H P, E U, T R, P B$ and TC initiated the study and conceptualized the study design. $\mathrm{PB}, \mathrm{TC}$ and NTT conducted the field work. AMR conducted the data analysis and wrote the draft version of the manuscript. PB supported the statistical analysis and revised the manuscript together with TR, EU and HP. All authors read and approved the final manuscript.}

\section{Ethics approval and consent to participate}

Not applicable.

\section{Consent for publication}

Not applicable.

\section{Competing interests}

The authors declare that they have no competing interests.

\section{Author details}

${ }^{1}$ Chair for Forest Growth and Yield Science, Center of Life and Food Sciences Weihenstephan, Technical University Munich, Hans-Carl-von-Carlowitz-Platz 2, 85354 Freising, Germany. ${ }^{2}$ Vietnamese Academy of Forest Sciences, Dong Ngac Commune, Tu Liem District, Hanoi, Vietnam. ${ }^{3}$ Tay Nguyen University, 567 Le Duan Stree, Buon Ma Thuot City, Dak La Province, Vietnam.

Received: 13 April 2018 Accepted: 25 September 2018

Published online: 02 November 2018

\section{References}

Akbari H, Pomerantz M, Taha H (2001) Cool surfaces and shade trees to reduce energy use and improve air quality in urban areas. Sol Energy 70(3):295-310. https://doi.org/10.1016/S0038-092X(00)00089-X

Armson D, Stringer P, Ennos AR (2013) The effect of street trees and amenity grass on urban surface water runoff in Manchester, UK. Urban For Urban Green 12(3):282-286

Arndt SK, Sanders GJ, Bristow M, Hutley LB, Beringer J, Livesley SJ (2015) Vulnerability of native savanna trees and exotic Khaya senegalensis to seasonal drought. Tree Physiol 35(7):783-791

Ballester J, Rodó X, Giorgi F (2010) Future changes in Central Europe heat waves expected to mostly follow summer mean warming. Clim Dynam 35(7-8): $1191-1205$

Bartens J, Day SD, Harris JR, Dove JE, Wynn TM (2008) Can urban tree roots improve infiltration through compacted subsoils for stormwater management? J Environ Qual 37(6):2048-2057. https://doi.org/10.2134/ jeq2008.0117

Bates D, Maechler M, Bolker B, Walker S (2015) Linear mixed-effects models using 'Eigen' and S4. https://cran.r-project.org/web/packages/Ime4/index.html. Accessed 23 July 2018 
Bell ML, Morgenstern RD, Harrington W (2011) Quantifying the human health benefits of air pollution policies: review of recent studies and new directions in accountability research. Environ Sci Pol 14(4):357-368

Bühler O, Kristoffersen P, Larsen SU (2007) Growth of street trees in Copenhagen with emphasis on the effect of different establishment concepts. Arboric Urban For 33(5):330-337

Bunn A, Korpela M, Biondi F, Campelo F, Mérian P, Qeadan F, Zang C, Buras A, Cecile J, Mudelsee M, Schulz M, Pucha-Cofrep D, Wernicke J (2015) Dendrochronology program library in R. https://cran.r-project.org/web/ packages/dpIR/index.html. Accessed 23 July 2018

Bussotti F, Pollastrini M, Killi D, Ferrini F, Fini A (2014) Ecophysiology of urban trees in a perspective of climate change. Agrochimica 58:247-268

Campelo F, Gutiérrez E, Ribas M, Sánchez-Salguero R, Nabais C, Camarero JJ (2018) The facultative bimodal growth pattern in Quercus ilex - a simple model to predict sub-seasonal and inter-annual growth. Dendrochronologia 49:77-88

Chmielewski FM, Rötzer T (2001) Response of tree phenology to climate change across Europe. Agric For Meteorol 108(2):101-112

Churkina G, Zaehle S, Hughes J, Viovy N, Chen Y, Jung M, Heumann BW, Ramankutty N, Heimann M, Jones C (2010) Interactions between nitrogen deposition, land cover conversion, and climate change determine the contemporary carbon balance of Europe. Biogeosciences 7:2749-2764

Coburn J (2009) Cities, climate change and urban heat island mitigation: localising global environmental science. Urban Stud 46:413-427

Cook ER, Holmes RL (1986) User manual for computer program ARSTAN. In: Holmes RL, Adams RK, Fritts HC (eds) Tree-ring chronologies of western North America: California, eastern Oregon and northern Great Basin, vol Chronology Series 6. University of Arizona, Tucson, pp 50-57

Daanen HA, Jonkhoff W, Bosch P, ten Broeke H (2013) The effect of globalwarming and urban heat islands on mortality, morbidity and productivity in the Netherlands. Paper presented at the 15th international conference on environmental ergonomics, Queenstown, pp 11-15 Feb 2013

Dahlhausen J, Biber P, Rötzer T, Uhl E, Pretzsch H (2016) Tree species and their space requirements in six urban environments worldwide. Forests 7(6):111

Davies ZG, Edmondson JL, Heinemeyer A, Leake JR, Gaston KJ (2011) Mapping an urban ecosystem service: quantifying above-ground carbon storage at a citywide scale. J Appl Ecol 48(5):1125-1134

de Groot RS, Wilson MA, Boumans RMJ (2002) A typology for the classification, description and valuation 709 of ecosystem functions, goods and services. Ecol Econ 41:393-408

de Martonne E (1926) Une novelle fonction climatologique: L'indice d'aridité. La Météorologie 21:449-458

Dimoudi A, Nikolopoulou M (2003) Vegetation in the urban environment: microclimatic analysis and benefits. Energ Buildings 35:69-76

DWD (2017) Deutscher Wetterdienst. Offenbach am Main: German Weather Service

Esper J, Cook ER, Schweingruber FH (2002) Low-frequency signals in long treering chronologies for reconstructing past temperature variability. Science 295:2250-2253

Fang J, Kato T, Guo Z, Yang Y, Hu H, Shen H, Zhao X, Kishimoto-Mo AW, Tang Y, Houghton RA (2014) Evidence for environmentally enhanced forest growth. PNAS 111:9527-9532. https://doi.org/10.1073/pnas.1402333111

FAO (2011) Strengthening capacities to enhance coordinated and integrated disaster risk reduction actions and adaptation to climate change in agriculture in the northern mountain regions of Viet Nam. http://www.fao. org/climatechange/34098-06187508355defb6b37704dcb214eda1b.pdf. Accessed 23 July 2018

Farrell C, Szota C, Arndt SK (2015) Urban plantings: 'Living Laboratories' for climate change response. Trends Plant Sci 20(10):597-599

Foster J, Lowe A, Winkelman S (2011) The value of green infrastructure for urban climate adaptation. Center for Clean Air Policy, Washington D.C

Gaoue OG, Ticktin T (2007) Patterns of harvesting foliage and bark from the multipurpose tree Khaya senegalensis in Benin: variation across ecological regions and its impacts on population structure. Biol Conserv 137(3):424-436

Gillner S, Bräuning A, Roloff A (2014) Dendrochronological analysis of urban trees: climatic response and impact of drought on frequently used tree species. Trees 28(4):1079-1093

Gillner S, Vogt J, Roloff A (2013) Climatic response and impacts of drought on oaks at urban and forest sites. Urban For Urban Green 12(4):597-605

Holmes RL, Adams RK, Fritts HC (1986) Tree-ring chronologies of western North America: California, eastern Oregon and northern Great Basin with procedures used in the chronology development work including users manuals for computer programs COFECHA and ARSTAN, chronology series VI. Laboratory of Tree-Ring Research, University of Arizona, Tuscon, Arizona

IPCC (2001) Climate change 2001: impacts, adaptation, and vulnerability. Cambridge University Press, Cambridge

IPCC (2014) Synthesis report. Cambridge Univ Press, Cambridge

Kauppi PE, Posch M, Pirinen P (2014) Large impacts of climate warming on growth of boreal forest since 1960. PLoS One 9(11):e111340. https://doi.org/ 10.1371/journal.pone.0111340

Kim Oanh NT, Upadhyay N, Zhuang YH, Hao ZP, Murthy DVS, Lestari P, Villarin JT, Chengchua K, Co HX, Dung NT, Lindgren ES (2006) Particulate air pollution in six Asian cities: spatial and temporal distributions, and associated sources. Atmos Environ 40(18):3367-3380

Klein T (2014) The variability of stomatal sensitivity to leaf water potential across tree species indicates a continuum between isohydric and anisohydric behaviours. Funct Ecol 28(6):1313-1320. https://doi.org/10. 1111/1365-2435.12289

Klemm W, Heusinkveld BG, Lenzholzer S, van Hove B (2015) Street greenery and its physical and psychological impacton thermal comfort. Landscape Urban Plan 138:87-98

Konarska K, Uddling J, Holmer B, Lutz M, Lindberg F, Pleijel H, Thorsson S (2015) Transpiration of urban trees and its cooling effect in a high latitude city. Int J Biometeorol 60(1):159-172. https://doi.org/10.1007/s00484-015-1014-x

Lee H, Holst J, Mayer H (2013) Modification of human-biometeorologically significant radiant flux densities by shading as local method to mitigate heat stress in summer within urban street canyons. Adv Meteorol 38:1-13

Morgenroth J, Buchan GD (2009) Soil moisture and aeration beneath pervious and impervious pavements. Arboric Urban For 35(3):135-141

Moser A, Rahman MA, Pretzsch H, Pauleit S, Rötzer T (2016a) Inter- and intraannual growth patterns of urban small-leaved lime (Tilia cordata mill.) at two public squares with contrasting microclimatic conditions. Int J Biometeorol 61(6):1095-1107. https://doi.org/10.1007/s00484-0161290-0

Moser A, Rötzer T, Pauleit S, Pretzsch H (2015) Structure and ecosystem services of small-leaved lime (Tilia cordata mill.) and black locust (Robinia pseudoacacia L.) in urban environments. Urban For Urban Green 14(4): $1110-1121$

Moser A, Rötzer T, Pauleit S, Pretzsch H (2016b) The urban environment can modify drought stress of small-leaved lime (Tilia cordata mill.) and black locust (Robinia pseudoacacia L.). Forests 7(3):71

Moser A, Uhl E, Rötzer T, Biber P, Dahlhausen J, Lefer B, Pretzsch H (2017) Effects of climate and the urban heat island effect on urban tree growth in Houston. Open J Forest 7:428-445

Nowak DJ, Crane DE (2002) Carbon storage and sequestration by urban trees in the USA. Environ Pollut 116:381-389. https://doi.org/10.1016/S02697491(01)00214-7

Nowak DJ, Dwyer JF (2007) Understanding the benefits and costs of urban forest ecosystems. In: Kuser JE (ed) Urban and community forestry in the northeast, vol 2nd. Springer, Heidelberg, pp 25-46

Oke T (1987) Boundary layer climate. University Paperbacks, New York

Perera PKP, Amarasekera HS, Weerawardena NDR (2012) Effect of growth rate on wood specific gravity of three alternative timber species in Sri Lanka; Swietenia macrophylla, Khaya senegalensis and Paulownia fortunei. J Trop Forest Environ 2:26-35

Phi TH, Strokova LA (2015) Prediction maps of land subsidence caused by groundwater exploitation in Hanoi, Vietnam. Resource-Efficient Technol 1:80-89

Pretzsch H (2010) Forest dynamics, growth and yield: from measurement to model. Springer, Heidelberg

Pretzsch H, Biber P, Schütze G, Kemmerer J, Uhl E (2018) Wood density reduced while wood volume growth accelerated in central European forests since 1870. For Ecol Manag 429:589-616

Pretzsch H, Biber P, Schütze G, Uhl E, Rötzer T (2014) Forest stand growth dynamics in Central Europe have accelerated since 1870. Nat Commun 5(suppl. 1):4967. https://doi.org/10.1038/ncomms5967

Pretzsch H, Biber P, Uhl E, Dahlhausen J, Schütze G, Perkins D, Rötzer T, Caldentey J, Koike T, van Con T, Chavanne A, du Toit B, Foster K, Lefer B (2017) Climate change accelerates growth of urban trees in metropolises worldwide. Sci Rep 7:1-10. doi:https://doi.org/10.1038/s41598-017-14831-w

R Core Team (2018) R: a language and environment for statistical computing. $R$ Foundation for Statistical Computing, Vienna http://www.R-project.org/. Accessed 23 July 2018 
Rahman MA, Moser A, Rötzer T, Pauleit S (2017a) Microclimatic differences and their influence on transpirational cooling of Tilia cordata in two contrasting street canyons in Munich, Germany. Agric For Meteorol 232:443-456

Rahman MA, Moser A, Rötzer T, Pauleit S (2017b) Within canopy temperature differences and cooling ability of Tilia cordata trees grown in urban conditions. Build Environ 114:118-128

Rahman MA, Stringer P, Ennos AR (2013) Effect of pit design and soil composition on performance of Pyrus calleryana street trees in the establishment period. Arboric Urban For 39:256-266

Rennenberg H, Loreto F, Polle A, Brilli F, Fares S, Beniwal RS, Gessler A (2006) Physiological responses of forest trees to heat and drought. Plant Biol 6:556-571

Rinn F (2003) TSAP-win: time series analysis and presentation for dendrochronology and related applications. Version 0.55 User reference, Heidelberg

Rinn F (2005) TSAP v3.6. Reference manual: computer program for tree-ring analysis and presentation. TSAP, Heidelberg

Roy S, Byrne JA, Pickering C (2012) A systematic quantitative review of urban tree benefits, costs, and assessment methods across cities in different climatic zones. Urban For Urban Green 11:351-363

Santamouris M (2014) Cooling the cities - a review of reflective and green roof mitigation technologies to fight heat island and improve comfort in urban environments. Sol Energy 103:682-703

Schmidt-Thomé P, Nguyen H, Pham L, Jarva J, Nuottimäki K (2015) Climate Change in Vietnam. In: Climate change adaptation measures in Vietnam. Development and implementation. Springer, Heidelberg, p 100

Searle SY, Turnbull MH, Boelman NT, Schuster WSF, Yakir D, Griffin KL (2012) Urban environment of new York City promotes growth in northern red oak seedlings. Tree Physiol 32(4):389-400

Seto KC, Fragkias M, Güneralp B, Reilly MK (2011) A meta-analysis of global urban land expansion. PLoS One 6:e23777. https://doi.org/10.1371/ journal.pone.0023777

Sjöman H, Hirons AD, Bassuk NL (2015) Urban forest resilience through tree selection-variation in drought tolerance in Acer. Urban For Urban Green 14 $858-865$

Speer JH (2012) Fundamentals of tree-ring research. The University of Arizona Press, Tucson

Tarhule A, Hughes MK (2002) Tree-ring research in semi-arid West Africa: need and potential. Tree-Ring Res 58:31-46

TEEB-The economics of ecosystems and biodiversity (2011) TEEB manual for cities: ecosystem services in urban management. http://www.teebweb.org. Accessed 23 July 2018

Tyrväinen L, Pauleit S, Seeland K, Vries S (2005) Benefits and uses of urban forests and trees. In: Konijnendijk C, Nilsson K, Randrup T, Schipperijn J (eds) Urban forests and trees. Springer, Berlin, Heidelberg, pp 81-114. https://doi.org/10. 1007/3-540-27684-x_5

Vieira J, Carvalho A, Campelo F (2018) Xylogenesis in the early life stages of maritime pine. Forest Ecol Manag 424:71-77

Wigley TML, Briffa KR, Jones PD (1984) On the average value of correlated time series, with applications in dendroclimatology and hydrometeorology. J Clim Appl Meteorol 23:201-213

Yoon TK, Park CW, Lee SJ, Ko S, Kim KN, Son Y, Lee KH, Oh S, Lee WK, Son Y (2013) Allometric equations for estimating the aboveground volume of five common urban street tree species in Daegu, Korea. Urban For Urban Green 12:344-349. https://doi.org/10.1016/j.ufug.2013.03.006

\section{Submit your manuscript to a SpringerOpen ${ }^{\circ}$ journal and benefit from:}

- Convenient online submission

- Rigorous peer review

- Open access: articles freely available online

- High visibility within the field

- Retaining the copyright to your article

Submit your next manuscript at $>$ springeropen.com 